\title{
Leading Change: Faculty Development through Structured Collaboration
}

\author{
Suzanne R. Painter and Christopher M. Clark \\ Mary Lou Fulton Teachers College, Arizona State University, \\ Tempe, Arizona, United States
}

\author{
Suzanne.Painter@asu.edu; CClark8@asu.edu
}

\begin{abstract}
There are relentless calls for innovation in higher education programs in response to media and policy-makers attention to such concerns as instructional quality, relevance to employment, costs, and time-to-degree. At the same time, the individual course remains the primary unit of instruction and there is little evidence of faculty development strategies to assist with changing core instructional practices. We faced that dilemma when we led an innovative doctoral program in educational leadership. Soon after beginning, we implemented a regular meeting of all faculty members teaching and advising in the program to address upcoming events and review student progress. Our retrospective analysis indicates that these meetings evolved as a practical and sustainable framework for faculty development in support of deep change for instructional practices. Here we describe the challenge of faculty development for change and draw lessons learned from our four years of leadership centered on experiential learning and community sense-making. We hope that program leaders who aspire to promote faculty development in conjunction with graduate program implementation will find these lessons useful.
\end{abstract}

Keywords: Faculty development, doctoral programs, reform, innovation, leadership

\section{Leading Change: Faculty Development through Structured Collaboration}

It is no easy task to change instructional practices in institutions of higher education (IHEs). Problems generally include cultures that are change averse, unnecessary processes, inefficient decision-making, contradictory accountability and reward systems, implementation strategies that are "unproductive or nonexistent," and inconsistent quality in the delivery of the core activities of learning, research and engagement (Fullan \& Scott, 2009, p. 33). At the department level, norms favor individualized construction of course syllabi, and there are few faculty rewards for adapting

Material published as part of this publication, either on-line or in print, is copyrighted by the Informing Science Institute. Permission to make digital or paper copy of part or all of these works for personal or classroom use is granted without fee provided that the copies are not made or distributed for profit or commercial advantage AND that copies 1) bear this notice in full and 2) give the full citation on the first page. It is permissible to abstract these works so long as credit is given. To copy in all other cases or to republish or to post on a server or to redistribute to lists requires specific permission and payment of a fee. Contact Publisher@InformingScience.org to request redistribution permission. programs and curricula to meet external needs (Fullan \& Scott, 2009; Hokka \& Etelapelto, 2014). Despite some broad outlines of skills and strategies needed to lead change (Fullan \& Scott, 2009; Hokka \& Etelapelto, 2014), academic leadership at the program level, including initiating, supporting and maintaining changes in instruction, is an understudied area (Scott, Coates, \& Anderson, 2008). Reports on new and exemplary 
practices abound but there is little guidance on how to engage all faculty members in changing their teaching practices over sustained periods.

We can draw some lessons from the extensive literature on the implementation of change in K-12 settings. This scholarship demonstrates that innovation is surprisingly complex. To enable success, change agents must address the behaviors, assumptions and beliefs of teachers in classrooms who are expected to change their practices. Teachers bring mental models (that is, internal representations of the concepts built from prior experience and knowledge) of teaching and learning to interpret and make sense of their teaching. These mental models filter perceptions and subsequent classroom actions (Elmore, 1996). When reformers try to implement their theory-based programs in K-12 classrooms, teachers implement the reform based on their previously developed mental models or theories-in-use, which are likely to be different than those of the reform developers (Coburn, 2003; Elmore, 1996; Hall \& Hord, 2014; McLaughlin \& Mitra, 2001). Reformers must recognize that deep change involving a substantive shift in teaching practices is not successful unless teachers understand how to live the theory behind the proposed change - the "first principles" - so that when they adapt the strategies to local micro-contexts they do so with fidelity to the theory (McLaughlin \& Mitra, 2001).

This article describes the early years of implementation of an innovative doctoral program that required significant changes in how faculty members taught and advised doctoral students. During the implementation, we realized that a meeting structure that we adopted primarily for communication became a vehicle for faculty development and support. To explain this outcome, we first address the literature on change, and then we describe how these meetings worked including a) our innovation implementation challenge, b) our actions, and c) results of our implementation efforts. Finally, we share our conclusions and implications.

\section{Changing Instructional Practices in Higher Education}

As noted above, teachers use their prior conceptions of teaching and learning to interpret and make sense of their teaching (Elmore, 1996). Often, they are unaware that the theories-in-use are not compatible with their espoused theories of teaching and learning (Argyris, 1980). This means, for example, that faculty members may be aware of and endorse social-cultural theories of learning and situated cognition, but unaware that their practices are not aligned with these theories. The challenge of faculty development is that of implementing new teaching practices and simultaneously engaging faculty in a re-examination of the assumptions, beliefs and traditions that have shaped their instructional and advising practices.

Two aspects of faculty learning appear to be critical: experiences and subsequent sense-making in community. To learn new ways of teaching, faculty members must act and reflect on their experiences. Rather than viewing learning as something transmitted through discourse alone, Kolb (1984) writes:

Experiential learning theory... proceeds from a different set of assumptions. Ideas are not fixed and immutable elements of thought but are formed and re-formed through experience... learning is described as a process whereby concepts are derived from and continuously modified by experience (p. 26).

Fullan and Scott (2009) say: "well-analyzed new experience precedes insight; behavioral change feeds into change in belief" (p. 52). Or more prosaically: "It's easier to act your way into a new way of thinking than think your way into a new way of acting" (Pascale, Sterrin, \& Sternin, 2010, p. 38). Creating conditions for faculty to act in new ways is a primary task of leadership.

Making meaning of the experience is a critical aspect of learning. All learning is socially and culturally mediated (Vygotsky, 1978; Wenger, 1998; Wenger, McDermott, \& Snyder, 2002). Within 
organizations, individuals engaged in similar tasks develop informal communities to tell stories that make sense of their work and assist each other with craft knowledge to solve problems that require application of knowledge and judgment (Brown \& Duguid, 1991; Wenger, 1998).

Workplace learning is best understood, then, in terms of the communities being formed or joined and personal identities being changed. The central issue in learning is becoming a practitioner, not learning about practice. This approach draws attention away from abstract knowledge and cranial processes and situates it in the practices and communities in which knowledge takes on significance (Brown \& Duguid, 1991, p. 48).

Faculty members' beliefs about teaching and learning are socially constructed from their local workplaces (the particular academic programs, departments and universities of which they are a part), as well as the workplaces of their particular disciplines - the research communities that hold particular norms about scholarly productivity, research methods and so forth. Their individual conceptions are built through interactions with others around the socially mediated cultural practices of their work. Thus the concepts of "doctoral study," "dissertation" or "rigor" are individually held, yet socially constructed. As Olson and Clark (2009), relying on Wenger (1998), put it:

... people construct and develop their identities and transform their thinking through their active participation and engagement with others in cultural-historical practices that are situated in social communities. Thus members of a community of practice interact, share and participate in the creation and re-creation of the practice and, through that engagement, develop, reify, and transform their identities (p. 217).

Learning, then, is both organizational and individual (Datnow, 2002; Hall \& Hord, 2014).

\section{Our Innovation and Implementation Challenge}

For four years, as faculty members in the Mary Lou Fulton Teachers College at Arizona State University, one or both of us served as academic program leaders for the doctorate of education (EdD) program. The program was the first approved to be delivered at the West campus of the University, and there was intense interest from the campus and university administrators in ensuring the program would be innovative and successful. A year of traditional planning processes had resulted in an approved curriculum and courses developed by individual faculty and approved through the curriculum process. The first cohort had been admitted but midway through the first semester, a number of these students met with the Dean and reported finding a lack of the innovation the program had promised. At that point, the Dean called on us to take over the leadership although we had not worked together previously. Our paramount considerations were: (a) what was the substance of the innovation that should be in place? (b) how could we engage faculty to enact innovation within a short time frame? We believe these challenges apply to many attempts to innovate and will resonate with program leaders who face similar challenges for quick action to implement deep change.

The doctoral students had been recruited for a program that would meet their needs as working professionals with both rigor and innovation. This commitment was aligned with our institution's stated principles describing "A New American University" including: (a) a focus on leveraging place (using and contributing to local knowledge); (b) transforming society; (c) conducting useinspired research; (d) enabling student success; and (e) being socially embedded with partners in our local community (Arizona State University, n.d.). Similarly, Sullivan and Rosin (2008) have called for universities to prepare doctoral students for "lives of significance and responsibility" and to assist students to "develop a life of the mind for practice" (p. xv). Critical analysis is not enough - practical reasoning leading to strategic action is needed. As Sullivan and Rosin (2008) put it: 
... a life of the mind for practice means the cultivation of reflection and criticism, such as advocates of critical thinking promote, but not for the sake of reflecting and criticizing alone. Rather, the point of such cultivation is that students must learn to deliberate about their possibilities for a life well-lived, including their responsibility to contribute to the life of their times. . f for practical reason the focus is on thinking that is oriented toward decision and action (p. xvi).

We benefitted from participating in the Carnegie Project for the Education Doctorate (CPED), initiated by Lee Shulman, to reinterpret and reinvigorate the education doctorate as a professional degree. Our colleagues at other institutions shared our aims and leadership challenges (DeLisi, 2013; Gallagher, 2013; Welch, 2013).

We envisioned a professional doctoral program that would have practitioners initiate and sustain locally led, evidence-informed change, and to sustain this practice after graduation. Our students, with few exceptions, were professional teachers or administrators in K-12 or Higher Education institutions, or working in organizations with an educational component. We sought to take advantage of the students' workplaces as "laboratories of practice" where students could implement and investigate new practices. At the same time, we had to work within the parameters of the approved course list and program requirements. Our key innovations to be implemented were:

1. We planned to engage students in cycles of action research in their workplaces, beginning with their first year of study and culminating with the final cycle reported in the dissertation. The aim was not to create new knowledge but to get into the game themselves, making change, studying it, and always improving, in preparation for a career of implementing and evaluating local change. This contrasted with our faculty's lived experiences of researchers being distanced from, rather than immersed in, the objects of their study.

2. We would embed these cycles in the required coursework each semester, which we reconfigured from two stand-alone three-credit courses to one six-credit team-taught course. Students began acting before they felt ready (and before they completed all courses in research methodology). We relied on social-constructivist and experiential learning. Thus, students would not be expected to learn how to do research in lecture classes, followed years later by application in their dissertation studies. Rather, our plan was to engage first semester doctoral students in clumsy initial pilot studies from which they would discover the shortcomings of methods and become seekers of information and tools to help them do better in the next cycle. These cycles were intended to scaffold their learning so that students could approach the dissertation with confidence rather than as a "sink or swim" test of their abilities.

3. We would group four to six students together with two faculty members who would work with them for the final two years of their three-year program. Collectively these groups would support all members in proposal development and completion of individual dissertations. These Leader-Scholar Communities (LSC's) were supportive environments for learning, group advising, problem-solving and mutual support (Olson \& Clark, 2009).

Most of our faculty members earned their doctoral degrees in traditional $\mathrm{PhD}$ programs that prepared them for a professional life as research-oriented faculty. These experiences shaped their mental models of doctoral work, including such concepts as:

- Dissertations should contribute new knowledge in a narrowly specialized field.

- Students should be thoroughly knowledgeable about research methodology prior to engaging in their own study. 
- The faculty advisor's expertise and interest is the primary criterion for assignment of advisees.

- Candidates demonstrate independence as researchers by conducting the study and writing the dissertation, with occasional feedback from the dissertation advisor.

Our faculty members' personal experiences with these models of doctoral student expectations did not prepare them to engage with doctoral study that differed in fundamental ways. Our changes asked faculty to abandon the traditional concept of the lone professor teaching a course and advising doctoral dissertations as he or she chooses and to disrupt the traditional independence of teaching with team planning and implementation. Moreover, doctoral students were full-time working professional educators. Their particular problems-of-practice would drive their research, rather than the research agenda of the professors. Faculty members' research, drawing on their deep and specialized expertise, focused on creating knowledge that could be generalized across contexts and published in academic journals. They were observers rather than direct ongoing participants in schools. In contrast, the students were immersed in the daily workplace demands of $\mathrm{K}-12$, community college, or four-year college institutions and were recognized as leaders within these contexts. As a result, their knowledge of their local organizational context was broad and deep, and they understood practical aspects of educational work through these workplace experiences. Moreover, rather than depart after the study concluded, as researchers do, the students would continue to practice in the same professional context, whether the innovation succeeded or failed. Academic publishing was of interest to some, but not all students and was not a requirement of their leadership positions.

Both researcher and practicing professional are critical education roles, but their interests are not aligned in the same way as it is between a traditional $\mathrm{PhD}$ student and advisor. The educational doctorate prepares professional educators to continue their practice as leaders (formal or informal) in educational organizations, deepening and enriching their practice with tools for understanding innovation, change, and action research. Just as medical doctors earn the MD to prepare for clinical practice rather than for a career in laboratory research, the educational doctorate prepares those who engage in the work of education itself and study their own practices in order to improve, rather than traditional scholarly research on education that seeks context-free generalizable findings. In sum, the students were seeking to learn from the professors, but they did not seek to become their academic descendants.

\section{Implementation of Changes}

As we began leading the program, we faced immediate and longer term challenges. Immediately, we had to arrange for the teaching of the spring semester courses. We also had to plan for recruitment and admission of the second cohort of students, to staff courses for the summer and ensuing academic year, and find faculty who could implement the LSCs for the first cohort that were scheduled to begin in nine months. No new faculty positions were planned.

The required spring semester courses were combined into one six-hour block, with one of us (Clark) taking a lead role. We recruited four faculty members to serve as co-teachers and advisors to the students in their first round of action research. This was our first action that required reflection and continuous adaptation - the lived experience of mentored co-teaching. This group of faculty met each week to plan for their teaching. During the summer, we found faculty willing to serve as committee chairs (leading an LSC and serving as the dissertation advisor) for five students each, beginning in the fall of the second year. With the dean's approval, this role constituted the workload equivalent of a three-credit class. In selecting these faculty members, we were mindful of Collins' (2001) finding about the importance of "getting the right people on the bus" and were supported in these decisions by the dean. 
Once participating faculty were identified, we began holding meetings of all faculty members who were either teaching courses or serving as LSC members. We termed this group the Doctoral Steering Committee (DSC) and it met every three to four weeks. Membership consisted of those teaching the core courses (six faculty members teaching three six-credit courses in two-person teams), and all faculty members leading the Leader-Scholar Communities (up to 16 different faculty members at any given time, some of whom were also course instructors). The original group of faculty was comprised of ten tenured or tenure-track faculty, four men and six women. In subsequent years, the group grew to sixteen faculty members, including up to three clinical (fixedterm) faculty members. All held terminal degrees. Over the years that we led the program, approximately 30 different faculty members participated.

The stated agenda for meetings was usually organized under two headings: first, a check-in time when members reported on students' current work and progress, including identification of any student that seemed to be struggling. The second agenda heading was operational items, e.g., what the requirements of the dissertation proposal would be, how the comprehensive examination would be handled, the format for public display of research, and so forth.

We had looming deadlines that forced action (what will the dissertation proposal look like?). This meant that we planned in real-time. As leaders, we generally prepared a proposed course of action or draft documents as the basis for discussion and action. During committee meetings, faculty members reviewed upcoming deadlines and current practices and made adjustments as necessary to achieve program goals. Having all faculty members present alerted us to possible problems, conflicts and uncertainties that could be addressed as planning occurred. Only after faculty had experienced the major innovations (team-teaching, cycles of research, mixed methods) did we conduct reviews with the expectation of change. Most often, we found that through acting, the faculty became supporters - even vociferous defenders - of the innovations, even where they had previously expressed doubts. It is important to note that the community, as we conceived it, was not a governance structure of selected individuals sanctioned by the organization. It was a committee-of-the-whole. Every faculty member who taught and advised students in the program was included in this community of practice. This was so because it is critical that the faculty members in contact with students are learning and this community was, above all, a learning community. It was a place where these faculty members could tell stories to make sense of their work and assist each other to solve problems. Within organizations, individuals engaged in similar tasks develop informal communities to tell stories that make sense of their work and to improve practice with mutually shared knowledge and judgment (Brown \& Duguid, 1991; Wenger, 1998).

We also drew on outside knowledge to address areas of concern. We sponsored experts in action research and in mixed methods to meet with faculty and enhance their knowledge. These presentations occurred after the faculty had begun to wrestle with the issues - thus presenting them with information after their experiences to help them expand and make sense of the learning.

\section{Results}

In evaluating the degree of success of the DSC meetings for faculty development, we present the following evidence. We gathered the evidence from published studies on the program's impact on students and faculty, student performance indicators (graduation rates, dissertation awards), and a review of program documents.

\section{Student Performance and Satisfaction}

Our commitment to students was that, with dedicated effort, all would finish in three years and every student in cohort one completed in this time frame. For the first five doctoral cohorts (classes of 2009 through 2013) 91\% of students who completed the first year graduated in three years. 
The others were enrolled and on track to finish within 2 years of their original anticipated completion, leaving no "all but dissertation" students. (Reasons for delayed graduation included job changes and illness.)

At the end of the first year, faculty reviewed the dissertations and expressed some dissatisfaction with a) the quality of the literature reviews, and b) the relatively weak use of conceptual frameworks. As a result, the advisors and course instructors for Cohort 2 (then beginning their second year) addressed these issues by revising the dissertation guidelines. This emphasis on examining the evidence (dissertation proposals and completed dissertations) continued through the second and third rounds of dissertations until faculty expressed more satisfaction with the quality. External validation supported in this general judgment when the Carnegie Project for the Education Doctorate recognized four ASU dissertations as exemplary in a blind review process open to all project member institutions. In addition, eight of the student-practitioners from the first five cohorts have co-authored articles in peer-reviewed journals and others have presented at national conferences, an outside indicator of quality.

Student evaluations were collected from the first cohort of students and reported in AmreinBeardsley et al. (2012). Students valued the LSC's as being supportive of their work, felt their identities had changed, and expressed a need for more structure and support in research methodologies. Subsequent studies of graduates have affirmed their changed identities with respect to action research implementation (Buss, Zambo, Zambo, \& Williams, 2014; Zambo, Buss, \& Zambo, 2013) and technology use (Ewbank, Foulger, \& Wetzel, 2012).

\section{Faculty Change and Satisfaction}

Faculty members' changes were reported by Buss, Zambo, Painter, \& Moore (2013). The changes included expanded views of research and changed views of teaching as a participatory, collaborative and student-centered activity. Faculty attributed the changes to the team-teaching, the Leader-Scholar Communities that fostered relationships with and between the students, and they especially noted the importance of the DSC meetings where they wrestled with the "messiness" of the work and mutually supported each other in staying focused on program purposes. Faculty also noted the program leadership in these meetings (we comment on this below) and the Dean's support.

Not unexpectedly, not all faculty members responded positively. Of the approximately thirty faculty members we involved over five years, we became aware of three who did not shift beliefs or practices during the time of their involvements. In contrast, after several years in the program, one of our respected senior professors said that participating in the program

... admitted me to a refreshingly collaborative community. The EdD faculty members regularly team-taught classes to enliven the exchange of ideas. We publically posted and revised our syllabi to increase coherence in the program's curriculum. We jointly compared students' research to inform our mentoring. The imperative during these dealings, unlike any I had experienced, was to respond constructively rather than posture academically. In sum, the intellectual activity and collaborative spirit of the EdD in Leadership and Innovation granted me a welcome second wind as I was ending my career in academia (D. Moore, personal communication, August 24, 2014).

This faculty member had been a participant and later a leader of the faculty group and expressed sentiments that we heard from others. Another professor found that leading LSCs was the highlight of his 25 years in higher education because of the powerful impact of his students' work on local schools and the professionally enriching relationships he saw forming between and among his students and fellow faculty members (K. Wetzel, personal communication, September 10, 2014). 


\section{Discussion}

As program leaders, we, too, learned from our lived experience. Weick, Suffield and Obstfeld (2005, p. 419) say "we act our way into belated understanding". We understand more about our leadership and the program trajectory now that we have handed it off to others. Below we share our retrospective understandings.

\section{Functions of the DSC as a Sense-making and Quality Enhancing Body}

The original focus of the DSC was pragmatic - making decisions about implementing the new program and keeping faculty informed. We see now that the DSC was the critical mechanism to insure the program was implemented "consistently, effectively, and sustainably" (Fullan \& Scott, 2009 , p. 37). As they recommend, we involved the people who were the front-line implementers in this work. Monthly meetings that surfaced student concerns quickly became problem-solving discussions. At least once each year, we scheduled a longer meeting specifically focused on reviewing the syllabi and courses. Faculty research on the program provided data to inform decisions (e.g., Wetzel \& Ewbank, 2013) and documented faculty changes (Buss, Zambo, Painter \& Moore, 2013; Zambo \& Isai, 2013). We worked continuously towards a better alignment of teaching to the end goals of effective action research cycles. We also brought in experts to help us conceptualize and operationalize action research and mixed methods. These activities sustained the program and enhanced its quality.

At the same time, the DSC meetings became places where faculty engaged in discussions about every aspect of the change in practice. Retrospectively, we see these communities as exemplars of the working-learning-innovating communities that, while solving problems of implementation, also serve to recreate and refine the identities of the members individually as faculty members and collectively as a work group (Brown \& Duguid, 1991).

\section{Focused Leadership}

Leaders influence the meanings that are constructed by groups. Fullan (2008, p. 49) explains: "Leaders have to provide direction, create the conditions for effective peer interaction, and intervene along the way when things are not working as well as they could." Leaders must be prepared to hold firm when faculty suggestions to return to previous practices are sparked by the struggle to master new skills and strategies, knowing that the impulse for regression will be transient until the skills are mastered - "the implementation dip" (Hall \& Hord, 2014). At the same time, some faculty suggestions for change will result from what is learned through implementation, and will result in improved student experiences. Leaders must discern the difference between these two types of faculty suggestions for change. We found that it was critical to ask for and acknowledge faculty thoughts about the innovative practices, and then to frame these issues within the context of our goals to serve practitioners with high expectations for rigor in sustainable action research. In this way, we could help faculty examine how the proposed change would (or would not) contribute to the learning of practitioners seeking terminal degrees. Two examples illustrate our dilemmas. Faculty members who were (understandably) inexperienced with supervising action research and challenged by students' grappling with problems of their own domains of expertise would occasionally propose that we not require the student to implement innovation, but allow them to conduct (for example) a program evaluation in another organization. Against this, we stood firm, as implementing change is a crucial aspect of practice in schools, whereas conducting external evaluations as "consultants" is not. Our students needed to grapple with the real world messiness of implementing innovation. On the other hand, faculty concerns about rigor of action research methods and weakness of conceptual frameworks could be (and were) addressed with 
changes to syllabi and course topics in ways that strengthened the programs' utility and richness for the students and served to further the program principles and aims. Practitioners need strong skills in these areas and we worked to enhance them.

\section{Faculty writing}

Faculty generated new streams of research from their participation in the program and developed new collaborations. Writing has inherent sense-making qualities (Weick, Sutcliff, \& Obstfeld, 2005 ) and tenured and tenure-track faculty members are rewarded for publishing. Therefore, there is a natural alignment between faculty interest in publications as a career-enhancing and writing to further a developing understanding of the content of reform and its theoretical bases. Unexpectedly, we found that our practitioner students were interested in co-authoring publications and faculty members were energized by their involvement.

\section{Participation}

As Wenger notes, some participants in a community of practice are peripheral - they do not necessarily fully share all the ideas and commitments of the group, nor take fully participative roles. We noted above that we were aware of three faculty members who we would judge as peripheral members. Fullan (2007) cites Marris' (1975) discussion of what it means to witness the conceptual struggle of those trying to implement an innovation, when change creates cognitive dissonance that precedes the reorganization of schema, "No one can resolve the crisis of [conceptual] reorganization for another" (p. 51). And to do so, he adds, is disrespectful of their agency.

As noted, it is important for leaders to hold fast to innovation principles through the turmoil of implementation, and this may mean that some participants leave voluntarily or involuntarily through re-assignment. We exercised judgment, with the support of the dean, in determining which faculty would participate. Some faculty were simply unsuited to this endeavor, either because they had records of difficulty in acting collaboratively (to use Fullan's (2007) term, they were not "prosocial") or because they were unable to modify their existing concepts of doctoral work (e.g., expressing disdain for action research, insistence on creation of "new disciplinary knowledge," inability to lead a LSC as a cohort). Other faculty members whom we recruited felt, at first, inadequate to the task and were pulled in with some reluctance on their part. They later became strong advocates for the innovations after seeing the effects on students and on themselves.

\section{Impermanence}

Finally, we learned to accept impermanence. Faculty members are reassigned to other duties, retire or move away. New people are added who haven't yet experienced the program's collective sense-making processes. New initiatives draw administrative attention and resources. Leaders must recognize that a program is not a series of decisions or documents, but an organic relationship (sometimes strong, sometimes weak) among faculty who are current participants. As with any socially-mediated practice, permanence of practice is an illusory concept. The most sustainable practice is the changed beliefs of faculty members that drive their future practices.

\section{Conclusion}

Our analysis indicates that the DSC evolved as a practical and sustainable framework for faculty development in support of deep change of instructional practices and faculty beliefs. The original purpose of establishing the DSC was to enable high fidelity implementation of a new doctoral program design. The early days of the DSC challenged us as leaders to both advocate for the new program design and to persuade faculty of their ability to flourish within it. Through involving them in program practices, before they were entirely committed, and providing a forum for dis- 
cussing their resulting reactions, we evolved into a learning community. We learned to live out our commitments to experiential learning and community sense-making. The program design in action was subjected to collective scrutiny, analysis in the light of direct experience of doctoral students and faculty, and willingness to make collectively designed adjustments on the fly. Faculty members changed their behavior as instructors and mentors and also continuously fine-tuned program requirements to better achieve overall program goals for their doctoral students.

Today, nearly one decade after the first cohort of students arrived on campus, the doctoral program continues to thrive and evolve, now double in size. The original goal of the program, to equip leaders in education to study and to improve their professional practice in context, is intact. Some faculty members who taught and mentored the early cohorts have retired or moved on to other responsibilities. Others remain in leadership positions and new faculty members have joined the community. The essential spirit of the Doctoral Steering Committee, to transform a program implementation exercise into a collective experiential learning process, served as transformative professional development for faculty and promoted impressive levels of student success and program reputation. We hope that program leaders who aspire to promote faculty development in conjunction with graduate program implementation will find these lessons useful.

\section{References}

Argyris, C. (1980). Inner contradictions of rigorous research. New York: Academic Press.

Arizona State University. (n.d.). Design aspirations. Retrieved from http://newamericanuniversity.asu.edu/design-aspirations/

Beardsley, A., Zambo, D., Moore, D., Buss, R., Perry, N., Painter, S., \& Puckett, K. S. (2011). Graduates respond to an innovative educational doctorate program. Journal of Research on Leadership Education $7(1), 98-122$.

Brown, J. S., \& Duguid, P. (1991). Organizational learning and communities-of-practice: Toward a unified view of working, learning, and innovation. Organization Science, 2(1), 40-57.

Buss, R. R., Zambo, D., Painter, S. R., \& Moore, D. W. (2013). Examining faculty member changes in an innovative educational doctorate program. Innovative Higher Education, 38, 59-74. http://dx.doi.org/10.1007/s10755-012-9222-3

Buss, R. R., Zambo, R., Zambo, D., \& Williams, T. R. (2014). Developing researching professionals in an EdD program: From learners and leaders to scholarly and influential practitioners. Higher Education, Skills and Work-based Learning, 4, 137-160. http://dx.doi.org/10.1108/HESWBL-11-2013-0022

Coburn, C. (2003). Rethinking scale: Moving beyond numbers to deep and lasting change. Educational Researcher, 32(6), 3-12.

Collins, J. (2001). Good to great: Why some companies make the leap and others don't. New York: HarperBusiness.

Datnow, A. (2002). Can we transplant educational reform and does it last? Journal of Educational Change, $3(3-4), 215-239$.

DeLisi, R. (2013). Reflection, reconstruction, and transformation of the EdD: A dean's perspective. Planning and Changing, 44(3/4), 127-139.

Elmore, R. F. (1996). Getting to scale with good educational practice. Harvard Educational Review, 66(1), $1-26$.

Ewbank, A. D., Foulger, T. S., \& Wetzel, K. A. (2012). Novice researchers find their power: Using technology to support the development of doctoral students. International Journal of Technology in Teaching and Learning, 8(2), 118-134.

Fullan, M. (2007). The new meaning of educational change. New York: Teachers College Press. 
Fullan, M. (2008). The six secrets of change. San Francisco: Jossey-Bass.

Fullan, M., \& Scott, G. (2009). Turnaround leadership for higher education. San Francisco, CA: John Wiley \& Sons.

Gallagher, K. S. (2013). Improving doctoral degrees in education: Focus on mission, coherence, and sustainability. Planning and Changing, 44(3/4), 140-148.

Hall, G. E., \& Hord, S. M. (2014). Implementing change: Patterns, principles and potholes ( $4^{\text {th }}$ ed.). Boston: Pearson.

Hokka, P., \& Etelapelto, A. (2014). Seeking new persepectives on the development of teacher education: A study of the Finnish context. Journal of Teacher Education, 65(1), 39-52.

Kolb, D. (1984). Experiential learning. Englewood Cliffs, NJ: Prentice-Hall.

Marris, P. (1975). Loss and change. New York: Anchor Press/Doubleday.

McLaughlin, M., \& Mitra, D. (2001). Theory-based change and change-based theory: Going deeper, going broader. Journal of Educational Change, 3(1), 301-323.

Olson, K., \& Clark, C. M. (2009). A signature pedagogy in doctoral education: The leader-scholar community. Educational Researcher, 38(3), 216-221.

Pascale, R., Sternin, J., \& Sternin, M. (2010). The power of positive deviance: How unlikely innovators solve the world's toughest problems. Boston, MA: Harvard Business Review Press.

Scott, G., Coates, H., \& Anderson, M. (2008). Leadership capabilities for australian higher education. Retrieved from http://research.acer.edu.au/cgi/viewcontent.cgi?article=1001\&context=higher_education

Sullivan, W. M., \& Rosin, M. S. (2008). A new agenda for higher education: Shaping a life of the mind for practice. San Francisco, CA: Jossey-Bass.

Vygotsky, L. (1978). Mind in society: The development of higher psychological processes. Cambridge: Harvard University Press.

Weick, K. E., Sutcliff, K. M., \& Obstfeld, D. (2005). Organizing and the process of sensemaking. Organization Science, 16(4), 409-421.

Welch, O. (2013). Interrogating our practice: Enacting a "yes and" CPED agenda at Duquesne University. Planning and Changing, 44 (3/4), 149-161.

Wenger, E. (1998). Communities of practice: Learning, meaning, and identity. Cambridge: Cambridge University Press.

Wenger, E., McDermott, R., \& Snyder, W. M. (2002). Cultivating communities of practice. Boston: Harvard Business School Press.

Wetzel, K., \& Ewbank, A. (2013). Conceptualizing the innovation: Factors influencing doctoral candidates' interventions in the action research dissertation. Educational Action Research, 21(3) 392-411. http://dx.doi.org/10.1080/09650792.2013.813402

Zambo, D., Buss, R. R., \& Zambo, R. (2015). Uncovering the identities of students and graduates in a CPED-influenced EdD program. Studies in Higher Education, 40(2). http://dx.doi.org/10.1080/03075079.2013.823932

Zambo, D., \& Isai, S. (2012). Lessons learned by a faculty member working in an education doctorate program with students performing action research. Educational Action Research 20(3), 471-477. http://dx.doi.org/10.1080/09650792.2012.697668 


\section{Biographies}

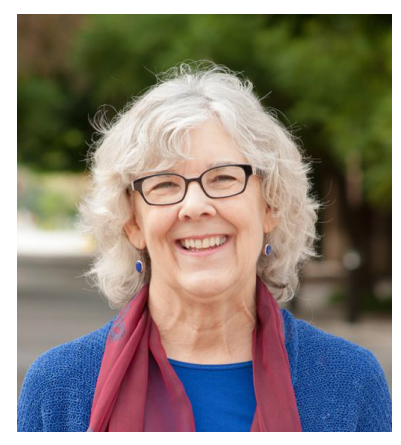

Suzanne Painter is an associate professor at the Mary Lou Fulton Teachers College at Arizona State University. Her research interests are in leadership development, teacher preparation, and higher education curricula. She currently teaches courses in instructional leadership and school law.

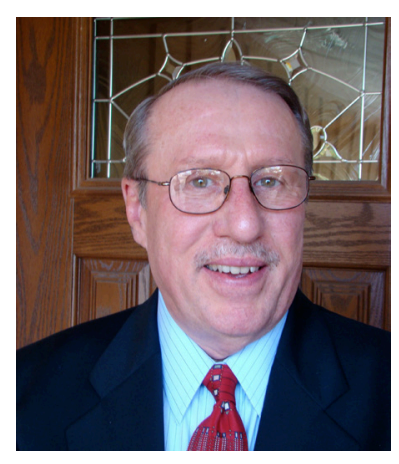

Christopher M. Clark is a researcher on teaching and teacher education affiliated with the Center for Advanced Studies in Global Education at the Mary Lou Fulton Teachers College, Arizona State University. 